Bangladesh J. Bot. 49(1): 65-70, 2020 (March)

\title{
RELATIONSHIP OF SEVERITY PRUNING AND WEATHER VARIABLES ON QUALITY FRUIT PRODUCTION OF BER (ZIZIPHUS MAURITIANA L. CV. SANAUR-2)
}

\author{
YOGESH KHOKHAR \\ Punjab Agricultural University, Dr DR Bhumbla Regional Research Station \\ Ballowal Saunkhri-144521 Punjab, India
}

Keywords: Ber, Severity pruning, Correlation, Fruit production, Powdery mildew

\begin{abstract}
Pruning had a vital role on the quality of fruit production in ber fruit crop under lower Shiwaliks of Punjab. The severity of pruning intensity significantly influenced the tree vegetative growth parameters and flowering behaviour of ber cv. Sanaur-2 viz. number of emerged shoots per branch, shoot length and girth of primary shoot. A significant higher percentage of fruit set, fruit retention, higher percentage of 'A' grade fruits and other fruit quality parameters viz., fruit weight, TSS, acidity, vitamin C, total sugars was recorded significantly higher in pruning treatment by removal 50 per cent vegetative growth over other treatments. Powdery mildew incidence steadily increased from standard meteorological weeks (SMW) 36 - 39 to 40 - 43 and then decreased under different pruning treatments. The severity of pruning reduces the incidence of powdery mildew. The meteorological knowledge on various weather variables at 3 - 4 weeks to actual incidence also can be effectively used to check the spread and severity of the disease.
\end{abstract}

\section{Introduction}

The Indian ber (Ziziphus mauritiana L.) is commonly grown in the sub-mountainous rain fed region of the Punjab. However, over the years, ber productivity start diminished with smaller fruits of inferior quality after bearing normal crops of 30 - 35 years. Pruning in ber is the pre-requisite for the better growth and quality of fruits as it bears on current season growth. The intensity of pruning in ber is dependent on several factors like genotype, spacing and climatic conditions where the fruit crop is being grown (Pandey et al. 1998). The regular pruning of ber trees improves the productivity and quality of fruits. Pruning intensity plays a great role in regulating fruiting in ber, it is usually done at third fortnight of April before starting new growth in the autumn (Singh and Bal 2008). Under the rainfed conditions the severity of pruning significantly affects the vegetative growth of primary, secondary and tertiary branches in ber cultivar ponda Safeda. The maximum primary branches were obtained with $25 \%$ pruning, whereas the highest numbers of secondary and tertiary branches were obtained with $50 \%$ pruning (Kumar et al. 2002). The judicious pruning in ber cv. Banarsi Karaka improves the quality of marketable fruit while severe pruning i.e. 60 per cent removal of vegetative growth promotes the subsequent vegetative growth (Kumar et al. 2014). The annual pruning is pre-requisite for improving the productivity and quality fruits as it replaces old and unproductive wood by new one, in unpruned trees, the old wood goes on accumulating every year and leads to barren centre, reduced productivity and poor fruit yield owing to shading and severe powdery mildew like problems. Therefore, in ber tree, pruning is a essential practice to maintain their vigour and quality fruit production. So, there is a need to standardize the extent of pruning intensity on quality fruit production with minimum disease incidence in ber cultivars. Keeping the above objectives in view the present study was conducted to assess the effect of different intensities of pruning on quality fruit production in ber.

*Author for correspondence: <khokhar82@pau.edu>. 


\section{Materials and Methods}

The present study was conducted on 32 years old ber plantation cv. Sanaur-2 at Regional Research Station, Ballowal Saunkhri under rainfed conditions during 2015-17. The varieties of ber Sanaur-2 were planted at $7.5 \mathrm{~m} \times 7.5 \mathrm{~m}$ spacing raised on Zizyphus mauritiana rootstock in randomized block design. Three replications under rainfed conditions were used as experimental material. Trees were headed back previous year as per recommended by the Punjab Agricultural University for the rejuvenation in the second fortnight of May. The cut surfaces were smeared with copper oxychloride to check the microbial infections. Out of numerous shoots emerged after 12 - 15 days, 1-2 shoots were kept and rest was removed periodically. The trees received uniform cultural operations throughout the experimental period and the whole of the orchard was kept clean. The trees were pruned with a view to improving the growth and production of fruits. The amount of fertilizer and manures was applied uniformly under all treatments. The experiment consists of three treatments viz., Control (No pruning), $\mathrm{T}_{1}$ : (25\% removal of vegetative growth), $\mathrm{T}_{2}$ : (50\% removal of vegetative growth) and $\mathrm{T}_{3}$ : (75\% removal of vegetative growth. The pruning was done on one year old shoots in the third week of May with the help of a secateurs and hand saw. The observations on vegetative characters like days taken to sprout, number of shoots emerged, shoot length and girth of primary shoot were recorded from five randomly selected trees in each treatment during October every year as per procedure reported by Ranganna (1997). Fruit yield ( $\mathrm{kg} /$ tree) over the years was calculated by taking all the harvested fruits on each picking at maturity and after that fruits were graded in large $(>35 \mathrm{~mm})$ medium $(35-25 \mathrm{~mm})$ and small grade $(<25 \mathrm{~mm}$ ) (Pareek and Gupta 1988) then calculated per cent contribution of A, B and C grade fruits in total fruit yield. The uniform fruits of ber cultivars were harvested and were then analyzed for their physico-chemical properties using 20 randomly selected fruits. Fruit and stone size were recorded by measuring the length and breadth using Vernier calipers, while weight was taken using top pan digital balance. The fruits from different samples were weighed and their volume was estimated by water displacement method and specific gravity was determined from the weight divided by fruit volume. The total soluble solids (TSS) were determined with Erma hand refractometer $\left(0-32^{\circ}\right.$ Brix $)$. The titratable acidity, total sugars and ascorbic acid contents were estimated by the standard methods described by Fassai (2016). The observations taken during middle of each month on per cent powdery mildew incidence in different months (September to December) was recorded and statistically analyzed. The correlation coefficients of weather variables with powdery mildew incidence were worked out using the weather data recorded at Agrometeorological observatory, Regional Research Station, Ballowal Saunkhri.

\section{Results and Discussion}

Tree vegetative growth parameters of ber cv. Sanaur-2 viz., number of emerged shoots per branch, shoot length and girth of primary shoot were significantly influenced by severity of pruning i.e $\left(T_{1}\right)$ and by removal of 25 per cent vegetative growth to $\left(T_{3}\right) 75$ per cent removal of vegetative growth. Maximum number of sprouted shoots per branch was recorded in $\left(\mathrm{T}_{3}\right)$ pruning by removal 75 per cent vegetative growth (Table 1). Similar observation was made by Singh et al. (2017). The fruiting behaviour and yield parameters such as days taken to flower initiation and days taken to $50 \%$ flowering were significantly affected by various pruning intensities (Table 2). A significant higher per cent fruit set (57.62) and fruit retention (41.21\%) was recorded in $\left(\mathrm{T}_{2}\right)$ pruning by removal 50 per cent vegetative growth over other treatments (Table 2). Significantly higher fruit set $(\%)$ and fruit retention $(\%)$ have been recorded in $\left(\mathrm{T}_{2}\right)$ pruning treatment which might be due to more open tree canopy resulted due to more light penetration that led assimilation of more photosynthetic materials in pruned shoots that needed for fruit setting. The present findings are in agreement with the findings of Khokhar (2017). The fruit yield decreased gradually 
with the increase in intensity of pruning (Table 3). The fruit yield $(56.14 \mathrm{~kg} /$ tree) was found highest in the $\left(\mathrm{T}_{2}\right)$ pruning treatment. Gupta and Gill (2015) recorded in the study of ber that reduction in the fruit yield may vary with severity of pruning which might be due to reduction in number of bearing shoots and use of assimilates in vegetative growth which lead to the less number of fruits per tree. Fruit yield was significantly increased with various pruning intensity of pruning. The fruit yield was recorded maximum $\left(56.14 \mathrm{~kg} /\right.$ tree) in pruning treatment $\mathrm{T}_{2}$ while

Table 1. Influence of severity of pruning on vegetative growth of ber cv. Sanaur-2.

\begin{tabular}{lcccc}
\hline $\begin{array}{l}\text { Pruning } \\
\text { intensity }\end{array}$ & $\begin{array}{c}\text { Days taken for } \\
\text { sprouting }\end{array}$ & $\begin{array}{c}\text { Number of shoots } \\
\text { emerged/branch }\end{array}$ & $\begin{array}{c}\text { Shoot length } \\
(\mathrm{cm})\end{array}$ & $\begin{array}{c}\text { Girth of } \\
\text { primary shoot }\end{array}$ \\
\hline Control & 36.21 & 25.31 & 26.58 & 19.32 \\
$\mathrm{~T}_{1}$ & 25.34 & 28.15 & 61.25 & 22.12 \\
$\mathrm{~T}_{2}$ & 21.52 & 28.34 & 87.42 & 20.14 \\
$\mathrm{~T}_{3}$ & 19.34 & 29.21 & 99.23 & 19.23 \\
$\mathrm{CD}(5 \%)$ & 1.32 & 1.21 & 2.14 & 0.14 \\
\hline
\end{tabular}

Table 2. Influence of severity of pruning on the flowering and fruit set of ber cv. Sanaur-2.

\begin{tabular}{lcccc}
\hline $\begin{array}{l}\text { Pruning } \\
\text { intensity }\end{array}$ & $\begin{array}{c}\text { Days taken to } \\
\text { flower initiation }\end{array}$ & $\begin{array}{c}\text { Days to 50\% } \\
\text { flowering }\end{array}$ & $\begin{array}{c}\text { Fruit set } \\
(\%)\end{array}$ & $\begin{array}{c}\text { Fruit retention } \\
(\%)\end{array}$ \\
\hline Control & 91.23 & 112.1 & 45.94 & 30.24 \\
$\mathrm{~T}_{1}$ & 93.45 & 119.2 & 51.23 & 38.28 \\
$\mathrm{~T}_{2}$ & 95.21 & 120.1 & 57.62 & 41.21 \\
$\mathrm{~T}_{3}$ & 94.56 & 119.5 & 56.34 & 40.28 \\
$\mathrm{CD}(5 \%)$ & 0.04 & 0.02 & 1.04 & 0.08 \\
\hline
\end{tabular}

Table 3. Influence of severity of pruning on the fruit yield of ber cv. Sanaur-2.

\begin{tabular}{lcccc}
\hline \multirow{2}{*}{$\begin{array}{l}\text { Pruning } \\
\text { intensity }\end{array}$} & $\begin{array}{c}\text { Fruit yield } \\
(\mathrm{kg} / \text { tree })\end{array}$ & $\mathrm{A}$ & $\mathrm{B}$ & $\mathrm{C}$ \\
\cline { 3 - 5 } Control & 36.23 & 56 & 35 & 9 \\
$\mathrm{~T}_{1}$ & 47.12 & 65 & 30 & 5 \\
$\mathrm{~T}_{2}$ & 56.14 & 80 & 14 & 6 \\
$\mathrm{~T}_{3}$ & 55.37 & 78 & 15 & 7 \\
$\mathrm{CD}(5 \%)$ & 3.21 & & & \\
\hline
\end{tabular}

minimum $(36.23 \mathrm{~kg} / \mathrm{tree})$ in the unpruned trees. The fruit quality significantly affected with severity of pruning. The production of 'A'grade fruits was $78-80 \%$ with moderate to severe pruning treatments (Table 3). The other quality parameters viz., fruit size in terms of fruit length and fruit breadth increased with the increase in intensity of pruning (Table 5). Similar results with respect to fruit size were also reported by (Kumar et al. 2002). All increased pruning treatments effectively increased the average weight of the fruit as compared to the control. The significantly 
higher fruit weight $(29.52 \mathrm{~g})$ was found under the treatment $\left(\mathrm{T}_{2}\right)$ pruning by removal 50 per cent vegetative growth and minimum $(14.62 \mathrm{~g})$ fruit weight was obtained in the trees kept under the control. Similar results were recorded with respect of fruit weight by Singh et al. (2010). The stone weight was observed significantly highest in the control (1.41) followed by the trees pruned under treatments $\mathrm{T}_{3}(1.39)$ and $\mathrm{T}_{1}$ (lowest) (Table 5). The pulp percentage was highest in the fruit under the treatment $\left(\mathrm{T}_{2}\right)$. The minimum pulp percentage was recorded in the unpruned trees. This may be due to the maximum fruit size and fruit weight and minimum stone weight under the treatment $\mathrm{T}_{2}$. The different pruning intensities had a significant effect on the TSS content of the ber fruit (Table 4). The maximum (18.15\%) TSS content was observed in $\mathrm{T}_{2}$ and minimum under unpruned. The higher TSS in $\left(\mathrm{T}_{2}\right)$ treatment of pruning may be due to more open tree canopy and thus allowing more light and less competition for the growth of individual fruit per tree canopy; while use of metabolites for vegetative growth in severely pruned trees might have resulted in lower TSS. The pruning treatment has not any significant effect on the acid content of the fruits. However, ascorbic acid and total sugars were recorded significantly higher in fruits obtained from severe pruning intensity than that of low to unpruned (Table 4).

Table 4. Influence of severity of pruning on the fruit quality of ber cv. Sanaur-2.

\begin{tabular}{llllll}
\hline $\begin{array}{l}\text { Pruning } \\
\text { intensity }\end{array}$ & $\begin{array}{l}\text { Fruit } \\
\text { weight }(\mathrm{g})\end{array}$ & TSS & Acidity & $\begin{array}{l}\text { Total } \\
\text { sugars }\end{array}$ & $\begin{array}{l}\text { Ascorbic } \\
\text { acid }\end{array}$ \\
\hline Control & 14.62 & 14.51 & 0.39 & 10.2 & 188.4 \\
$\mathrm{~T}_{1}$ & 25.74 & 15.82 & 0.42 & 10.8 & 186.5 \\
$\mathrm{~T}_{2}$ & 29.52 & 18.15 & 0.41 & 12.2 & 236.3 \\
$\mathrm{~T}_{3}$ & 28.41 & 16.23 & 0.43 & 12.1 & 212.1 \\
$\mathrm{CD}(5 \%)$ & 1.32 & 0.01 & 0.03 & 0.04 & 1.41 \\
\hline
\end{tabular}

Table 5. Influence of severity of pruning on the fruit length, breadth, stone weight and pulp of ber cv. Sanaur-2.

\begin{tabular}{lllll}
\hline $\begin{array}{l}\text { Pruning } \\
\text { intensity }\end{array}$ & $\begin{array}{l}\text { Fruit length } \\
(\mathrm{mm})\end{array}$ & $\begin{array}{l}\text { Fruit breadth } \\
(\mathrm{mm})\end{array}$ & $\begin{array}{l}\text { Stone weight } \\
(\mathrm{g})\end{array}$ & $\begin{array}{c}\text { Pulp } \\
(\%)\end{array}$ \\
\hline Control & 3.90 & 2.97 & 1.41 & 94.23 \\
$\mathrm{~T}_{1}$ & 4.31 & 3.34 & 1.34 & 95.34 \\
$\mathrm{~T}_{2}$ & 4.67 & 3.69 & 1.23 & 96.57 \\
$\mathrm{~T}_{3}$ & 4.49 & 3.53 & 1.39 & 96.14 \\
$\mathrm{CD}(5 \%)$ & 0.02 & 0.07 & 0.05 & 0.01 \\
\hline
\end{tabular}

The average powdery mildew incidence on ber cultivar Sanaur-2 clearly indicated that incidence was steadily increased from standard meteorological weeks (SMW) 36 - 39 to 40 - 43 and then decreased under different pruning treatments (Fig. 1). However maximum incidence was recorded in control trees and minimum in $\mathrm{T}_{3}$ pruning treatment (Fig. 1). The relationships of powdery mildew incidence period from initiation to completion of disease (lead period) with various weather variables are presented in Table 6. The mean maximum temperature was significantly positively related with powdery mildew incidence at three $(0.47)$ to four $(0.43)$ weeks 
lead period. However, the effect of minimum temperature was significant at two weeks $(0.51)$ lead time. A significant and negative relationship of the mean relative humidity was $(-0.57)$ observed at five weeks lead time. Thus, it is concluded from above results that, meteorological data on different variables at $3-4$ weeks lead time can be suitably used for the management of disease. The total rainfall was significantly negative correlated with the disease incidence at four weeks lead time,

Table 6. Relationship of various pruning levels with powdery mildew incidence and weather variables under rainfed conditions.

\begin{tabular}{llllllll}
\hline Weather & Range & Pruning & \multicolumn{5}{c}{ Lead time (Weeks) } \\
\cline { 4 - 7 } variables & & treatments & 5 & 4 & 3 & 2 & 1 \\
\hline Maximum temp. $\left({ }^{\circ} \mathrm{C}\right)$ & $17.2-37.7$ & $\mathrm{~T}_{1}$ & -0.14 & 0.13 & -0.14 & -0.37 & -0.59 \\
& & $\mathrm{~T}_{2}$ & 0.23 & 0.32 & 0.37 & -0.32 & -0.29 \\
& & $\mathrm{~T}_{3}$ & 0.49 & 0.62 & 0.56 & -0.24 & -0.29 \\
& & Control & 0.32 & 0.43 & 0.47 & -0.32 & 0.17 \\
Minimum temp. $\left({ }^{\circ} \mathrm{C}\right)$ & $1.8-23.2$ & $\mathrm{~T}_{1}$ & -0.12 & 0.58 & 0.42 & -0.59 & -0.49 \\
& & $\mathrm{~T}_{2}$ & 0.15 & 0.24 & 0.56 & -0.53 & -0.35 \\
& & $\mathrm{~T}_{3}$ & 0.42 & -0.56 & 0.76 & -0.54 & 0.43 \\
& & Control & 0.35 & 0.23 & 0.26 & 0.51 & 0.23 \\
Relative humidity $(\%)$ & $59.9-85.9$ & $\mathrm{~T}_{1}$ & 0.39 & -0.45 & 0.29 & 0.52 & 0.65 \\
& & $\mathrm{~T}_{2}$ & -0.59 & -0.45 & 0.32 & 0.19 & 0.41 \\
& & $\mathrm{~T}_{3}$ & -0.79 & 0.56 & 0.17 & -0.67 & 0.39 \\
Rainfall & & Control & -0.57 & -0.18 & 0.29 & -0.13 & 0.15 \\
& $0-105.2$ & $\mathrm{~T}_{1}$ & 0.45 & -0.65 & 0.16 & 0.43 & 0.34 \\
& & $\mathrm{~T}_{2}$ & 0.15 & -0.67 & 0.34 & 0.56 & 0.59 \\
& & $\mathrm{~T}_{3}$ & -0.12 & -0.69 & 0.37 & 0.67 & 0.64 \\
& & Control & -0.26 & -0.37 & 0.42 & 0.23 & 0.31 \\
\hline
\end{tabular}

*SMW = Standard meteorological weeks.

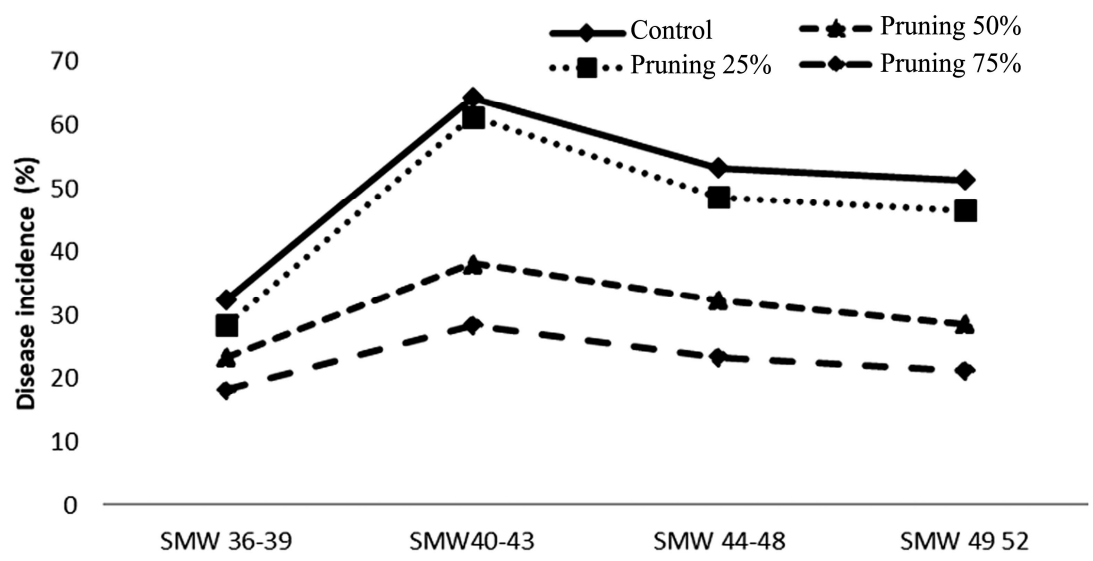

Fig. 1. Per cent disease incidence on ber in relation to pruning in different SMW. 
whereas it was positive at, three to two weeks lead period, respectively at various levels of pruning. The severity of pruning showed a significant negative association with rainfall. The maximum temperature showed a significantly positive $(0.62)$ relation with only in $\left(\mathrm{T}_{3}\right)$ pruning treatment. However, minimum temperature was significantly and positively related with all the pruning treatments $\left(T_{1}\right)=0.42,\left(T_{2}\right)=0.56$ and $\left.\left(T_{3}\right)=0.76\right)$ at four weeks lead period. Similarly, RH at four weeks lead time had significant negative impact on all the pruning levels $\left(\mathrm{T}_{1}\right)=-0.45$, $\left(\mathrm{T}_{2}\right)=-0.46$ and $\left.\left(\mathrm{T}_{3}\right)=-0.56\right)$.

\section{Acknowledgement}

The author is grateful to Director, RRS Ballowal Saunkhri for providing necessary facilities.

\section{References}

Fssai 2016. Quality analysis of fruits. In: Manual of analysis of fruit and vegetable products, food safety and standards authority of India, Ministry of Health and Welfares Government of India, pp. 1-56 New Delhi.

Gupta N and Gill MS 2015. Effect of intensity of pruning on yield and fruit quality of ber (Ziziphus mauritiana L) cv. UMRAN. International J. Agri. Environ. \& Biotech. 8(1): 69-73.

Khokhar Y 2017. Pruning and productivity of old unprofitable ber cultivars in lower Shiwaliks of Punjab J. Hill. Agric. 8(4): 414-416.

Kumar H, Katiyar PN, Singh AK and Rajkumar BV 2014. Effect of different pruning severity on growth and yield of ber (Zizyphus mauritiana L.) cv. Banarsi Karaka. International J. Curr. Microb.\& Appl. Sci.3(5):935-940.

Kumar S, Ram SN and Baig MJ 2002. Effect of pruning levels on yield and quality of ber (Zizyphus mauritiana L.) cultivars. Range Management Agroforest. 23(1): 59-62.

Pandey RC, Pathak RA and Singh IS 1998. Effect of pruning intensity on vegetative and reproductive growth in ber (Zizyphus mauritiana Lamk.). Indian J. Hort. 55(4): 306-313.

Pareek, O P and Gupta O P 1988. Packaging of ber, datepalm and phalsa. A souvenir on packaging of fruits and vegetables in India. Agri-Horti. Society, Hyderabad, India. 91-103.

Ranganna, S. (1997). Manual of Analysis of Fruit and Vegetable Products. Tata McGraw Hill Pub Co Ltd, New Delhi

Singh R and Bal JS 2008. Pruning in ber (Zizyphus mauritana Lamk.) Agric. Review. 29(1): 61-67.

Singh S, PratapB Yadav A and Shivam 2017. Assess the effect of pruning and plant growth regulators on growth, flowering and fruiting of ber tree. J. Pharm. \& Phyto. 6(5): 735-738.

Singh S, Singh B and Singh, M 2010. Influence of time and severity of pruning on vegetative growth, fruit quality and yield of ber cv. Umran. National Seminar on recent trends and development, CCS. HAU. Hissar : 57-58.

(Manuscript received on 19 July, 2018; revised on 16 April, 2019) 